\title{
Reflections on the Ideological and Political Education of College Students in the New Media Era
}

\author{
Shiliang Xu \\ Liaoning Railway Vocational and Technical College, Jinzhou, 121000, China
}

502255951@qq.com Keywords: new media; ideological and political education; college students; colleges and
universities

\begin{abstract}
The impact of new media on society is becoming more and more significant, which indicates that human society has entered a new era of information technology. The new media is widely used in college students, and becomes popular in the university classroom. However, the new media is a "double-edged sword", it is an important means of communication and access to information, but there are some drawbacks. This paper focuses on the innovation thinking of ideological and political work of college students in the new era, hoping to have a certain reference for ideological and political education in Colleges and universities.
\end{abstract}

\section{Introduction}

In the second half of twenty-first Century, the information revolution impels the human society to enter a new era -- the era of new media information. This makes the ideological and political education in Colleges and universities face the reality of the background with new features: one is that college ideological and political education environment becomes more complicated, teacher and student, form, method, means and concepts of ideological and political have emerged a new situation, it is urgent to explore new methods and effective way to deal with; Second is that the new media technology promotes the overall development of human society, making great change of channels of information dissemination, speed and mode, which have enormous impact on College Students' Ideological and political education and also brought new opportunities for ideological and political education for colleges and universities. Therefore, if teachers can make full use of the positive impact of new media, analyse the causes the negative effects, effectively solve the new situation and new problems faced by College Ideological and political education, the effectiveness of the ideological and political education in Colleges and universities in the new media era will certainly be improved.

\section{The Definition of the New Media Era}

\section{Concept of Media.}

The word "media" originates from the Latin "Medius", which is commonly used in the word "medium", but there are slight differences in usage. The meaning of "The media" is more specific than "medium", it refers tools, channels, carrier, intermediary or technical means, which people use to transfer information and access to information, such as: CD, disk or digital media, text, sound, graphics etc.. The media should have certain space conditions, including information transmission conditions, time, receiver, etc., these are the elements of the media operation.

\section{Definition of New Media.}

Compared with "old", "New" is a process of change, development and extension, "new media" in essence reflects the historical category. As a new information transmission and communication, New media is the product of development of mass media, which is based on the development of digital technology, computer network technology and mobile communication technology, including computer, broadband, digital TV, virtual network, blog, search engine, WeChat, SMS, MMS, broadcast, mobile phone newspaper etc.. People divide media into traditional media and new media according to the habit and the chronological of production and use, the traditional media include 
newspapers, radio and television, the new media refer to the Internet and mobile networks. New media, what we call today, will eventually be replaced by the day after, therefore, the concept of new media based on the present also reflects a certain historical category.

The definition of new media in this paper is that, based on computer network technology or relying on mobile communication technology, using broadband network (including wired or wireless) to transmit information or data, as the high speed, digital and open information space provide information transmission and communication services for audience and disseminators.

\section{Characteristics of New Media.}

Equality and Freedom of New Media. Publication procedure of traditional media represented by newspapers, radio and television is more complex, provided by specialized departments to the relevant departments to approve on every chain one by one, which reflects unequal between the communicator and the audience. While the new media information is released and provided by the public, anyone can use new media platforms or tools of their own, to have a freedom speech, express their own views, which reflects the freedom and equality of the audience. Especially in the virtual world, anyone can hide their identity, which is not only the effective protection of freedom of expression, but also reflects the freedom of the new media.

The Universality and Timeliness of Information Content. The Internet will connect the world as one family, which reflects the universality of new media information content. As long as you tap the keyboard, the world is in your fingertips. People can use cell phone text messages, WeChat, microblog to know everything in the world in the shortest time. From the perspective of social development, citizens can use new media to konw public information released by government, students and parents through the campus network, QQ group, WeChat group know education information released by school, everybody can use new media platform to know real-time information about life, work, entertainment and the leisure.

Interactive. The information exchange of the traditional media shows the characteristics of one way, the public can only accept information, the information feedback is slow, and the interaction is poor. The new media makes the information exchange become two-way between the sender and receiver and both sides have the right to speak in the communication. In addition, digital technology makes it easy to collect information and people can complete the information release and reception in a short time.

\section{The Influence of the New Media Era on the Ideological and Political Education of College Students}

The new media is a double-edged sword, which brings challenges and opportunities to the ideological and political education in colleges and universities.

The Challenge of New Media to the Ideological and Political Education in Colleges and Universities.

The New Media Bring Some Erosion to College Students' Thoughts and Ideas. Currently college students in the 90s are the main body of education, who are active in thinking, have strong ability to accept new things, mainly for mobile phones, the Internet and other emerging media. The new media play an active role in promoting the building of a harmonious society, the development and prosperity of socialist culture, and the dissemination of socialist core values. However, it also has a negative effect in the disseminating negative information, for example: by WeChat, QQ, SMS, MMS and other ways to spread pornographic information; release reactionary remarks and negative information through the Internet, micro-blog and blog; These information will have a profound impact on the students who's world, life, value outlook have not yet fully formed, and even affect the stability and harmony of society.

New Media Easily Lead to Physical and Mental Health Problems of College Students. Mobile phones and the Internet as the representative of the new media with vivid and novel visual impact and colorful content attract people to try and use. College students as the audience of new media are particularly vulnerable to indulge. At present, the main problems of college students are the series of problems, such as addicted to mobile phones in class and after class, the online game addiction, 
and the virtual dating, and even the physical and mental health problems, interpersonal problems. In many colleges, teacher gives a lecture seriously on the podium, while students daze. Phenomenon that students indulge in mobile phone in class is not a case, greatly affecting the teaching quality; students addicted to online games break the learning and life balance; and some students use the virtual network to make friends and have romantic relationship; in recent years, female students lost contact events occur frequently, the network virtual threaten reality security. All these are affecting the students' psychological and physical health.

New media make college students fall into a crisis of integrity. The new media has the characteristics of virtual, people can have any speech, make anonymous communication with people in specific application, use virtual identity to release any information. This leads college some students with fluke mind step on the Internet fraud road, which makes the new media communication group fall into a credit crisis, or even thrown the students into prison.

\section{Opportunity brought by new media to the ideological and political education of college students.}

The new media provides a platform for ideological and political work. Openness and interactivity are important features of the new media. People can use it to communicate with each other and get the information they need. Another major feature of the new media is that you can use the Internet to achieve one to one, one to many or many to many exchanges. Mobile phone, computer can be said the most popular to college students and highest frequency used by them, so the ideological and political work can be carried out whenever and wherever possible to take advantage of new media communication and information.

The new media is well received and welcomed by college students. What's the best use of mobile phone, computer configuration attracts college students, which is inseparable with new media function, mainly because the new media shows a strong image, vivid information, the most timely, consistent with the trend ,deeply attract students attention; Compared with the traditional media, new media has fast transmission speed, low price, wide coverage, extensive source, so students can use their own carrier whenever and wherever possible to know. In the ideological and political work, teachers can choose the form which is easy to be accepted by students according to the characteristics of students and get the best results.

New media has become an indispensable carrier of college classroom and leisure activities. In the classroom, the new media is an important means to improve the quality of teaching. In the face of the increasingly loud slogan of teaching reform, the new media is an important breakthrough to promote the reform of teaching, multimedia, micro lessons, and other forms of teaching make ideological and political education run through the whole process of education and teaching. After the classroom, a series of thematic education activity are carried out through the new media platform, promoting good class atmosphere. In addition, teachers using WeChat, QQ, blog answer questions and communicate at any time to achieve an effective combination of teaching in class and management after class, promoting students' self-management, self-education and self-discipline.

\section{Reflections on college students' ideological and political work innovation in the New Media Era}

\section{Integrate the socialist core values into the whole process of ideological and political education of college students.}

Socialist core values are the essence of socialist ideology. Therefore, integrating the socialist core values into the whole process of ideological and political education work, we should adhere to socialist theories with Chinese characteristics, the people-oriented Scientific Outlook on Development as a guide, adhere to the people-centered education, moral education first principle, with the ideal and faith education at the core, to help students understand the truth in life, establish a scientific world outlook, the noble life outlook, correct value outlook, to cultivate students' sense of social responsibility, innovation spirit and practice ability, and guide students to foster common ideals and firm faith and strive for the great rejuvenation of the Chinese nation. Colleges and universities should firmly grasp the dominant ideology, purify the network environment, resist the 
invasion of the negative concept, and ensure the multi and harmonious new media culture. At the same time, the ideological and political work in colleges and universities should make full use of the advantages of new media to make sure the socialist core values could be deeply rooted in the whole process of College education.

\section{Give full play to the role of the main channel of ideological and political class.}

The use of new media is an important means to improve the effectiveness of ideological and political classroom. Teaching feedback based on the college students shows that ideological and political lessons are not taken seriously, the main reasons are the following: First, students think that professional courses as the "stepping-stone to success" is more important than the ideological and political course which is not essential. Second, students accept the "moral" class learning from primary school, cultivating the "conflict emotion" to the ideological and political. Third, currently due to the development of information technology, students are addicted to phone, mobile games, dating software, affecting the quality of lectures. Forth, the dull classroom atmosphere and the boring teaching theory make students lack of motive and the interest. The main reason is that the strong theoretical course can not fully mobilize the enthusiasm and initiate students, therefore, teachers should improve the understanding of teaching reform, transforming "theory teaching" to "student-based education", and make full use of multimedia technology.

\section{Strengthen the construction of "three aspects".}

Firstly, strengthen the construction of ideological and political education team through training, On the one hand, strengthen the technical training on new media to improve the application ability of the new media and give full play to the positive role of new media in the ideological and political education work. On the other hand, the ideological and political workers need to seriously study the dissemination of knowledge and communication skills, in the information age, educator should spread of the ideological and political education information based on the characteristics of new media, to improve the efficiency of ideological and political education work. Secondly, innovate of ideological and political work platform, through setting up the carrier and building the platform, occupy the ideological position of new media network. Thirdly, establish a new media team with high quality in the student cadres, which is conducive to expand the space of Ideological and political education work, to enhance the effect of the work, and to cultivate student cadres.

\section{Conclusion}

Nowadays, the influence of new media on human society is growing increasingly. as long as educators master the new media's characteristics and put it into the Ideological and political work, grasp the innovation ideas of college students' ideological and political work of the new media, new ways of Ideological and political education work will be explored.

\section{Reference}

[1] Zhang Xu. Reflections on the Ideological and Political Education of College Students in the New Media Era[J]. Heilongjiang Science. 2016(17).

[2] Xu Baofeng. Reflections on the Ideological and Political Education of College Students in the New Media Era[J]. Examination weekly. 2015(59).

[3] Li Hai. Reflections on the Ideological and Political Education of College Students in the New Media Era[J].Time Education. 2015(09).

[4] Fan Qi. Reflections on the Ideological and Political Education of College Students in the New Media Era[J]. The Science Education Article Collects. 2014(08).

[5] Li Yuanyuan. Reflections on the Ideological and Political Education of College Students in the New Media Era[J]. Journal of Kaifeng Institute of Education. 2014(04).

[6] Wang Zhanni, Chen Qiaoling. The way of Invisible Ideological and Political Education of College Students in the Internet Era[J]. Science and Technology Outlook. 2016(35). 